\title{
Etika Bisnis Pengusaha Muslim Terhadap Pelayanan Konsumen Dalam Meningkatkan Daya Beli Masyarakat \\ (Studi Kasus Pedagang Pusat Pasar Kota Padangsidimpuan)
}

\author{
Rosnani Siregar \\ Lecturer of Economics and Business Islam Faculty at IAIN Padangsidimpuan \\ Regar_nani@yahoo.co.id
}

\begin{abstract}
Urgency business can not be underestimated. Businesses play a vital role (important) in the social life of all time. Where economic power has the same meaning with political forces, so the urgency of the business can affect all levels of individual, social, regional, national and international. Thus any economic system as long as it guarantees necessary to uphold justice must be human. The involvement of Muslims in the trade is strongly associated with their religious understanding of the principles of life that always put the stocking of mercy for all the worlds. In this context Muslim traders consider trading business in a noble work and the legitimacy of the prophet of Allah. Traders may do with the accounts payable system to market consumer goods. Accounts payable that do not contain elements of usury. Consumers should not neglect the payment of debts to merchants, so that no dispute. In determining the price of the merchandise, the merchant must provide the appropriate price to the market price of each consumer. Merchants must provide khiyar rights for consumers, according to the rules khiyar in Islamic law. If it has been so ethical entrepreneurs in serving customers, then customers will shop and increase purchasing power in Muslim merchant stores.
\end{abstract}

Key Words: The Ethics of Entrepreneurs Muslim In the Serve Customers

\begin{abstract}
Abstrak
Urgensi Bisnis memang tak bisa diremehkan. Bisnis memainkan peranan vital (penting) dalam kehidupan sosial sepanjang masa. Di mana kekuatan ekonomi memiliki arti yang sama dengan kekuatan politik, sehingga urgensi bisnis dapat mempengaruhi semua tingkat individu, sosial, regional, nasional dan internasional. Jadi setiap sistem ekonomi asalkan itu menjamin perlu untuk menjunjung keadilan harus dilakukan manusia. Keterlibatan Muslim di perdagangan sangat terkait dengan pemahaman agama mereka tentang prinsip-prinsip hidup yang selalu menempatkan penebaran rahmat bagi seluruh alam. Dalam konteks ini para pedagang Muslim menganggap bisnis perdagangan dalam pekerjaan mulia dan legitimasi nabi Allah. Para pedagang dapat melakukan dengan akun sistem hutang untuk memasarkan barang-barang konsumen. Account hutang yang tidak mengandung unsur riba. Konsumen sebaiknya tidak mengabaikan pembayaran utang kepada pedagang, sehingga tidak ada sengketa. Dalam menentukan harga barang, pedagang harus memberikan harga sesuai dengan harga pasar setiap konsumen. Pedagang harus memberikan hak khiyar bagi konsumen, menurut aturan khiyar dalam hukum Islam. Jika sudah begitu etika pengusaha dalam melayani pelanggan, saat itu pelanggan akan berbelanja dan meningkatkan daya beli di toko-toko pedagang Muslim.
\end{abstract}

Kata Kunci : Etika Pengusaha Muslim Dalam Melayani Konsumen 


\section{PENDAHULUAN}

\section{LATAR BELAKANG}

Urgensi bisnis tidak dapat dipandang sebelah mata. Bisnis memegang peranan vital (penting) didalam kehidupan sosial sepanjang masa. Dimana kekuatan ekonomi mempunyai kesamaan makna dengan kekuatan politik, sehingga urgensi bisnis dapat mempengaruhi semua tingkat individu, sosial, regional, nasional dan internasional. Oleh sebab itu, saat ini jutaan muslim yang terlibat berbagai kegiatan bisnis yang ada di persada bumi ini.

Keterlibatan muslim dalam dunia bisnis bukan merupakan penomena baru pada tahun 2012 ini. Hal ini sudah terjadi sejak abad ke VI dimasa Rasulullah masih hidup. Rasulullah terlibat dalam kegiatan bisnis selama bertahun-tahun. Rasulullah adalah seorang Pedagang, dan beliau sangat jujur dalam berbisnis. Dengan kejujurannya, dagangannya selalu diminati masyarakat. Banyak orang senang kepadanya kerena kejujurannya.

Sejarah menyatakan bahwa Islam itu berkembang melalui jasa para pengusaha atau Pedagang arab. Dimana mereka menjalankan bisnis dengan konsep yang diajarkan oleh Nabi Muhammad saw. Sehingga pada abad 13 mereka sampai berdagang ke Indonesia dan Islam pun berkembang disini.

Keterlibatan orang-orang Islam dalam berdagang sangat terkait dengan pemahaman keagamaan mereka tentang prinsip-perinsip hidup yang selalu mengutamakan penebaran rahmat bagi sekalian alam. Kehadiran muslim dimuka bumi ini membawa kebaikan kepada alam beserta isinya manfaat dan kebaikan-kebaikan yang ditawarkan ajaran islam tidak hanya untuk penganutnya sendiri tetapi juga bagi seluruh umat manusia. Dalam konteks inilah Pedagang muslim menganggap usaha dibidang perdagangan merupakan pekerjaan yang mulia dan mendapat legitimasi dari rasulullah saw. ${ }^{1}$

عن رافع بن خديج انه قيل يا رسول الله أي الكسب أطيب قال عمل المرء بيده وكل بيع مبرور رواه احمد والبزار وراواه الطبران عن ابن عمر بسند رواه ثنقات

Artinya: Dari Rafi' Ibn Khudaij, sesungguhnya seseorang bertanya kepada Nabi saw.:

"Ya Rasulallah pekerjaan apa yang paling baik?, Rasulullah bersabda:

“Pekerjaan seorang laki-laki dengan usahanya sendiri, dan jual beli yang baik'.

Dalam kontek ini Islam menjauhkan umatnya dari perbuatan riba, yang dalam perinsipnya siapa saja yang menghindarkan riba seperti yang diajarkan al-Qur'an akan mendapatkan kemaslahatan. Sebaliknya siapa saja yang melanggarnya maka akan sesangsara. Di samping itu islam juga menekankan prisip-prinsip keadilan, maslahah, amanah, jujur dan sebagainya yang merupakan nilai instrinsik manusia. Maksudnya 
siapa saja tanpa membedakan suku, agama, dan ras, semuanya membutuhkan keadailan maslahah, amanah dan kejujuran terutama dalam perdaganangan. Nilai-nilai tersebut merupakan kebutuhan universal yang melampaui sekat-sekat keagamaan. ${ }^{2}$

Dengan demikian sistem ekonomi apapun selama ia menjamin untuk menegakkan keadilan pastilah dibutuhkan manusia. Oleh karena itu Islam sebagai ajaran yang sempurna menegakkan nilai-nilai keadilan, kemaslahatan dan nilai lainnya terhadap umatnya sebagai sebuah sistem yang dapat digunakan oleh pemeluknya ataupun orang-orang yang berada diluar Islam tetapi menyakini keadilan dan kemaslahatan sistem ekonomi Islam tersebut.

Pada saat ini banyak pengusaha muslim menghadapai masalah yang sangat dilematis di dunia bisnis. Masalah yang dihadapi pengusaha muslim saat ini antara lain : persaingan dagang dengan orang non muslim, terutama orang keturunan Tionghoa (cina) mulai menguasai pangsa pasar. Dengan tingginya persaingan tersebut, warga keturunan mulai menguasai konsumen. Keadaan ini terjadi akibat kelalaian atau kesombongan, atau kurang beretika pengusaha muslim dalam melayani konsumen. Padahal dapat diketahui bisnis tanpa etika akan membawa kehancuran bagi pebisnis tersebut.

Bisnis yang tidak didasari dengan etika bisnis Islam dapat dilihat melalui catatan sejarah di Indonesia. Pada tahun 1997 mulai terjadi krisis moneter yang berkepanjangan di Indonesia. Awal terjadinya krisis moneter di Indonesia dengan adanya liberalisasi ekonomi. Dimana banyak pengusaha yang punya uang 10 miliyar membuka usaha perbankan. Suku bunga cukup rendah, sehingga banyak pengusaha yang memanfaatkan hutang luar negeri. Pada saat dollar naik, maka secara otomatis jumlah suku bunga pembayaran naik, hutang bertumbuk, dan muncul masalah kredit macet, dan berakibat pengusaha mulai ingkar janji karena tidak mampu membayar hutangnya. Sehingga nama Indonesia cukup rendah dimata internasional. Banyak orang yang tidak percaya lagi dengan pemerintah akibat ulah pebisnis yang tidak bermoral.

Dampak krisis moneter ini juga sampai ke kota padangsimpuan. Salah satu dampak krisis moneter di daerah ini adalah sembako langka dan harga naik, pekerja banyak di PHK dari perusahaan-perusahan atau pabrik karena suku bunga pinjamin naik. Pengaruh krisis ini masih kita rasakan sampai saat ini. Terbukti bahwa pekerja yang bukan angkatan kerja serta pengangguran cukup banyak dikota padangsidimpuan.

Profesor Edwards membedakan lima jenis pengerahan kerja yang tidak optimal, yaitu:

1. Pengangguran terbuka (open unemployment).

2. Pengangguran terselubung (unemployment). 
3. Mereka yang nampak bekerja tetapi sebenarnya kurang.

a. Pengangguran terselubung yang terlindung

b. Pengangguran yang tersembunyi

c. Pensiun terlalu dini

4. Mereka yang tidak mampu secara penuh.

5. Mereka yang tidak produktif. ${ }^{3}$

Kelima jenis pendapat Edward ini kita temukan semua di Kota Padangsidimpuan. Seandainya kota Padangsidimpuan tidak terimbas krisis moneter 1997 dan krisis global tahun 2008, maka kota ini tingkat penganggurannya rendah. Tingginya tingkat pengangguran akan mengakibatkan tingginya tingkat kejahatan di suatu daerah.

Biasanya, pengusaha yang terimbas dari dampak krisis moneter dan global adalah para pengusaha yang tidak punya prilaku bisnis islami atau dengan kata lain tidak punya etika bisnis yang diajarkan oleh agama islam dalam menjalankan usahanya. Sedangkan pengusaha yang punya prilaku islami atau punya etika bisnis islam tidak terkena dampak atau imbas krisis moneter dan global tersebut. Fakta ini dapat kita lihat pada tahun 1998 banyak bank yang dimerger atau dilkuidasi, namun bank muamalat tetap utuh dan semakin berkembang hingga saat ini.

Berdasarkan fakta penelitian di atas, penulis tertarik untuk meneliti tentang bagaimana prilaku atau etika para pengusaha muslim dalam menjalankan usaha seharisehari dalam melayani konsumen, sistem pelayanan berdagang para pengusaha, cara bisnis apa yang mereka pakai sehingga usaha mereka bisa berjalan lancar sesuai yang mereka inginkan. Penelitian tersebut akan diwujudkan dalam sebuah karya ilmiyah berbentuk penelitian indipidual yang berjudul : "Etika Bisnis Pengusaha Muslim Terhadap Pelayanan Konsumen Dalam Meningkatkan Daya Beli Masyarakat (Studi Kasus Pedagang Pusat Pasar Kota Padangsidimpuan)"

\section{Perumusan Masalah}

Adapun yang menjadi rumusan masalah dalam penelitian ini adalah :

a. Bagaimana prilaku atau etika para pengusaha muslim dalam melayani konsumen.

b. Bagaimana sistem pelayanan pengusaha muslim terhadap konsumen.

c. Bagaimana pengaruh etika pengusaha muslim dalam melayani konsumen terhadap tingkat daya beli masyarakat.

\section{Tujuan Penelitian}

Adapun tujuan dari penelitian ini adalah :

${ }^{3}$ Michael P. Todaro, Pembangunan Ekonomi Di Dunia Ketiga, (Jakarta, Edisi Ke Enam Penerbit Erlangga, 1999) hlm.. 290 
a. Untuk mengetahui prilaku atau etika para pengusaha muslim dalam melayani konsumen ketika menjalankan usaha sehari-sehari.

b. Untuk mengetahui sistem pelayanan berdagang para pengusaha muslim terhadap konsumen.

c. Untuk sosialisasikan Etika Bisnis Syariah bagi Pengusaha dalam melayani konsumen

\section{Kegunaan Penelitian}

Adapun kegunaan penelitian ini adalah sebagai berikut :

a. Untuk menjadi sumbangan pemikiran bagi para pengusaha muslim untuk menjalankan perdagangan yang islami.

b. Sebagai bahan acuan bagi para peneliti untuk memperkokoh landasan dalam pelaksanaan penelitian terapan dari para pengusaha muslim untuk menjalankan perdagangan yang islami.

c. Untuk menjadi bahan bacaan dan pedoman bagi para pelaku ekonomi, Pedagang muslim.

\section{Defenisi Operasional Konsep}

Depenisi operasional konsep penelitian ini diuraikan untuk memberikan kemudahan memahami judul dan maksud penelitian ini. Istilah-istilah yang perlu dijelaskan diantaranya adalah:

a. Etika Bisnis, yaitu prilaku bisnis secara etis dalam berbagai aktivitasnya artinya usaha yang dilakukan mampu memupuk dan membangun tingkat kepercayaan dari relasinya yang terkait dengan kejujuran, kepercayaan, dan keadilan sebagai elemen pokok dalam mencapai kesuksesan suatu bisnis. ${ }^{4}$

b. Pengusaha Muslim Kota Padangsidimpuan yaitu pengusaha atau Pedagang muslim yang menjalankan bisnisnya di pusat Kota Padangsidimpuan.

c. Studi Kasus yaitu mempelajari secara mendalam tentang peristiwa atau perilaku hukum yang terkait dengan masalah tertentu, dalam hal ini peristiwa hukum yang dimaksudkan adalah etika bisnis yang dijalankan oleh para Pedagang muslim yang berada di pusat Kota Padangsidimpuan.

d. Pedagang Pusat Pasar Kota Padangsidimpuan, yaitu para Pedagang muslim yang melalukan transaksi bisnisnya (toko) di Pusat Pasar Kota Padangsidimpuan

\section{METODDOLOGI PENELITIAN}


Penelitian ini menggunakan penelitian naturalistik. Penelitian naturalistik ini disebut dengan metode kualitatif. Metode kualitatif adalah metode penelitian yang digunakan untuk meneliti pada kondisi objek alamiah, dimana peneli adalah sebagai instrumen kunci. ${ }^{5}$

Maka, yang menjadi objek dalam penelitian ini adalah Etika bisnis para pengusaha (pedagang) dalam melayani konsumen di Pusat Pasar Kota Padangsidimpuan. Dalam penelitian ini, penulis ingin mendeskripsikan tentang prilaku atau etika para pengusaha muslim dalam menjalankan usaha sehari-sehari dari sudut pandang orang yang diteliti (imforman). Selanjutnya dari deskripsi tersebut ingin ditemukan penjelasan tentang sistem pelayanan berdagang para pengusaha. Oleh karena itu penelitian ini relevan jika didekati dengan menggunakan metode penelitian kualitatif. Dengan demikian, dalam penelitian ini diperlukan kata-kata atau keterangan dari orang-orang yang terlibat langsung atau orangorang yang ada hubungannya dengan objek penelitian ini, baik secara lisan maupun tulisan. Sesuai dengan apa yang dikatakan Bogdan dan Taylor yang mendefenisikan metode penelitian kualitatif dengan prosedur penelitian yang menghasilkan data deskriptif berupa kata-kata tertulis atau lisan dari orang-orang dan prilaku yang diamati. ${ }^{6}$

\section{HASIL PENELITIAN}

\section{Etika Bisnis Pengusaha Muslim Terhadap Pelayanan Konsumen Dalam Meningkatkan Daya Beli Masyarakat}

\section{a. Utang-Piutang}

Utang merupakan kegiatan yang biasa dilakukan dalam kehidupan seharihari. Terkadang utang ini dapat menimbulkan persoalan dalam kehidupan bermasyarakat. Persolan tersebut sangat sulit di atasi, sehingga dapat menimbulkan pertengkaran, dan bahkan persoalan tersebut sampai diajukan dan berproses perdamaian di kantor Pengadilan. Terkadang kasus tersebut tidak dapat selesai melalui pengadilan, maka terjadilah pembunuhan dalam penagihan hutang tersebut. Dalam Sebuah hadis Rasulullah saw. Beliau bersabda : Orang-orang yang menunda membayar hutang, bagi orang yang mampu adalah satu kezaliman. (Muttafaqun ’alaih).

Terkait dengan kegiatan perdagangan antara penjual dan pembeli di Pusat pasar kota Padangsidimpun bentuk hutang piutang yang dilaksanakan adalah penjual memberikan kesempatan kepada pembeli untuk menghutang barang yang dibelinya dengan kesempakatan pembayaran secara cicilan atau sekaligus. Sikap seperti ini merupakan perilaku bisnis yang baik karena adanya unsur ta'awuniah dalam bisnis tersebut. Dari 40 pedagang yang diteliti penulis 34 pedagang memberikan jawaban bahwa mereka memberikan kesempatan kepada pelanggan

${ }^{5}$ Riduwan, Belajar Muda Penelitian Untuk Guru-Karyawan dan Peneliti Pemula,(Bandung, Alfabeta,2005),

${ }^{6}$ Lexy Moleong, Metodologi Penliltian Kualitatif, (Bandung: Remaja Rosda karya: 1989), hlm., 3 
mereka untuk menunda pembayaran barang yang mereka ambil dari penjual. ${ }^{7}$ Bagi para pedagang, teknik seperti ini termasuk menarik para pembeli unuk membeli barang dagangannya. Sebagaimana diungkapkan oleh seorang pedagang kain Pasar Sagumpal Bonang:

Kita sering memberikan kesempatan kepada para penjual yang sudah kita kenal dan menjadi langganan kita untuk berhutang terhadap barang kain yang diambil di toko kita. Dengan cara seperti ini pembeli kita harapkan terikat pada kita dan tidak beralih kepada penjual lainnya." 8

Perilaku bisnis seperti ini biasanya terjadi antara pedagang grosir dengan para pembeli dari daerah-daerah lain untuk dijual kembali di pekan-pekan daerah mereka. Biasanya mereka datang dari pelosok-pelosok kampung dengan membawa modal terbatas. Ketika mereka menemukan barang yang bagus dan model baru mereka berusaha memperolehnya walaupun dengan berhutang terlebih dahulu kepada pedgang grosir di Pusat pasar Kota Padangsidimpuan. Banyaknya para penjual eceran dipelosok-pelosok perkampungan dari berbagai daerah sekitar Kota Padangsidimpuan menjadikan pusat pasar Kota Padangsidimpuan sebagai kota perdagangan.

Kebaikan yang diberikan oleh para pedagang Grosir Pusat kota Padangsidimpuan terhadap para pedagang dari pelosok-pelosok dengan memberikan kesempatan untuk berhutang terhadap barang yang mereka beli, terkadang tidak dibalas dengan kejujuran para pedagang pelosok tersebut. Ada beberapa orang pedagang dari pelosok yang sudah berhutang kepada pedagang grosir pusat Kota Padangsidimpuan tidak membayar hutang mereka pada rentang waktu yang cukup lama. Bahkan mereka sengaja tidak membeli barang lagi pada pedagang grosir tempat mereka berhutang tetapi pindah ke toko pedagang grosir lain. Dari 40 pedagang pusat pasar Kota Padangsidimpuan ada 7 pedagang yang mengakui prilaku pedagang dari pelosok yang berhutang kepada para pedagang grosir kota Padangsidimpuan seperti tersebut di atas. Mereka juga mengalami kerugian yang tidak sedikit akibat ketidak jujuran para pedagang dari pelosok tersebut. Bahkan ada seorang pedagang grosir pasar Sagumpal Bonang yang bangkrut karena prilaku pedagang dari pelosok yang tidak membayar hutangnya sesuai perjanjian. ${ }^{9}$

\section{b. Tidak Boleh Menghadang Orang Desa Di Perbatasan Kota}

Pada saat sekarang ini sering para tengkulak masuk ke desa-desa terpencil untuk membeli barang hasil pertanian dan harga ditentukan oleh tengkulak atau

${ }^{7}$ Wawancara dengan pedagang kain di Pasar Sagumpal Bonang dan Pelaza Anugrah pada bulan Nopember 2012

${ }^{8}$ Wawancara dengan seorang pedagang di Pasar Sagumpal Bonang pada bulan Nopember 2012.

${ }^{9}$ Wawancara dengan para Pedagang Grosir Pusat Pasar Kota Padangsidimpuan bulan Nopember 2012 
pedang kota yang datang ke desa tersebut. Penetapan harga tersebut dilakukan dengan cara intimidasi dan memberikan informasi yang salah kepada para petani. Contoh : harga cabai hari ini turun di pasar, padahal sebenarnya harga cabai naik di pasaran. Sikap seperti ini dilarang oleh Rasulullah saw. berdasarkan sabdanya : Janganlah kalian hadang kafilah-kafilah dan janganlah orang-orang kota menjual buat orang desa. (Muttafaqun 'alaih).

Sistem perdagangan seperti ini bertujuan untuk menekan harga serendah mungkin untuk dapat dijual kembali pada level harga yang paling tinggi. Pihak yang paling diuntung dengan sistem dagang seperti ini hanyalah para tengkulak yang terjun langsung ke pelosok-pelosok desa. Sementara para petani sangat dirugikan. Kegiatan ekonomi seperti ini biasanya dilakukan oleh para pedagang buah-buahan dan sayur mayur. Untuk saat sekarang ini sistem dagang seperti ini sudah jarang terjadi. Perkembangan tekhnologi informasi memberikan kemungkinan kepada para petani untuk mengetahui harga pasaran di kota. Mereka tidak dapat lagi ditipu dan dibodoh-bodohi oleh para tengkulak dari kota.

Pelambungan harga juga terjadi pada para pedagang di pusat pasar Kota Padangsidimpuan. Pelambungan harga ini biasanya dilakukan oleh pedagang eceran atau non-grosir. Harga barang dinaikkan sampai $150 \%$ sehingga para pembeli yang memeberikan penawaran terhadap harga yang ditawarkan tetap saja mereasa dirugikan. Dari beberapa pembeli yang diwawancarai penulis semuanya memberikan komentar bahwa memberikan penawaran dalam transaksi jual beli di sekitar pusat pasar kota Padangsidimpuan harus dua pertiga dari harga yang ditawarkan. Misalnya seorang penjual yang menawarkan harga barang dengan dua ratus lima puluh ripuah, seorang pembeli harus menawar sebesar seratus ribu rupiah atau bahkan tujuh puluh ribu rupiah. Menurut mereka penawaran seperti ini harus dilakukan karena tingginya markup harga dari modal yang dilakukan oleh para pedagang. ${ }^{10}$

Pencantuman harga pada barang yang akan dijual dengan penawaran diskon sampai $75 \%$ tidak menjamin kesesuaian harga dengan modal barang yang dijual. Penetapan diskon sampai $75 \%$ berarti pelambungan harga mencapai $150 \%$ sehingga pembelian barang tersebut tetap memberikan keuntungan pada pedagang sebanyak 50\% lagi. Bentuk penjualan seperti ini dijumapai pada pedagang pusat pasar Pelaza Anugrah Kota Padangsidimpuan. Bagi pembeli yang sudah memahami bentuk perdagangan seperti ini tentu saja dapat menghindari kerugian dari sistem dagang seperti ini, namun bagi mereka yang kurang memahaminya 
akan tertipu dengan pelambungan harga melalui sistem diskon harga sampai pada tingkatan tujuh puluh lima persen tersebut.

\section{c. Jual beli harus jujur dan ada hak khiyar}

Pelaku jual beli harus jujur dan tidak boleh dibuat kata sumpah dalam menunjukkan bahwa pedagang jujur dalam melaksanakan transaksi jual beli. Kejujuran dari para pedagang dapat dilihat pada berbagai aspek yaitu:

1) Penetapan harga dari modal yang telah di keluarkan. Artinya harga suatu barang diperhitungkan setelah modal secara keseluruhan diperhitungkan untuk mendapatkan barang tersebut. Ketika akan menetapkan harga, kenaikannya dari haga modal tidak boleh lebih dari seratus persen. Kenaikan paling tinggi dari harga modal hanyalah lima puluh persen. Ketika seorang penjual menaikkan harga seratus persen sebenarnya ia telah melakukan perbutan zhalim terhadap pembeli.

Kenaikan harga di pusat pasar Padangsidimpuan sangat berbeda dengan harga yang dianggap rasional dan lajim dalam ekonomi syari'ah. Para pedagang menaikkan harga barang mereka lebih dari seratus persen bahkan ada yang sampai seratus lima puluh atau dua ratus persen. Berdasarkan hasil penelitian penulis dari 40 orang pedagang eceran kebanykan dari mereka menaikkan harga antara seratus sampai seratus lima puluh persen. Untuk lebih jelasnya dapat dilihat pada tabel berikut ini.

Tabel I

Peruktuasi Kenaikan Harga Barang dari Modal Pusat Pasar Kota

\begin{tabular}{|c|c|c|c|}
\hline No & $\begin{array}{c}\text { Pruaktiasi } \\
\text { kenaikan harga } \\
\text { dari modal }\end{array}$ & $\begin{array}{c}\text { Jumlah } \\
\text { Pedagang }\end{array}$ & Persentase \\
\hline 1 & $50 \%$ s/d 100\% & 4 & $10 \%$ \\
\hline 2 & $100 \%$ s/d 150\% & 27 & $67.5 \%$ \\
\hline 3 & $150 \%$ s/d 200\% & 11 & $27.5 \%$ \\
\hline \multicolumn{2}{|c|}{ Jumlah } & 40 & $100 \%$ \\
\hline
\end{tabular}

Dari tabel di atas terlihat bahwa hanya 10 persen pedagang yang menetapkan harga antara $50 \mathrm{~s} / \mathrm{d} 100$ persen sementara 67.5 persen menetapkan harga antara $100 \mathrm{~s} / \mathrm{d} 150$ persen dan 27,5 persen berani mentapkan harga mencapai 200 persen. Penetapan harga yang dibuat oleh para pedagang pusat pasar Kota Padangsidimpuan ini merupakan harga penawaran bukan harga pinal. Pembeli yang lihai melakukan penawaran tidak dapat tertipu oleh pelambungan harga ini namun bagi pembeli yang tidak memiliki kemapuan melakukan penawaran mereka 
akan mengalami kerugian karena membeli barang dengan harta yang tidak sesuai dengan kuialitas barang.

\section{Kualitas barang yang diperjual belikan}

Pada dasarnya Jual Beli disyaratkan sahnya jual beli harus memiliki persyaratan sebagai berikut: Pertama, keridhoan antara penjual dan pembeli. Kedua, orang yang berakad memang diperbolehkan melakukan transaksi, seperti ia sudah baligh, berakal, merdeka, dan pintar. Ketiga, penjual memiliki barang dagangan yang dijual, atau ia berdiri sebagai pemilik barang tersebut, seperti wakil, wali, wasiat, atau yang diberikan hak. Tidak sah jual beli seseorang terhadap barang yang bukan miliknya. Sabda Rasulullah SAW kepada Al Hakim bin Hazam ra, "Jangan kau menjual apa yang bukan milikmu." (HR. Ahmad, Abu Daud, Nasa'i, Tirmidzi, Ibnu Majah, Shohih Al Albani). Makelar boleh selama ia menempati posisi sebagai pemilik barang selama sesuai dengan kaidah yang syar'i. Keempat, yang dijual adalah yang dibolehkan untuk dimanfaatkannya. Seperti makanan, minuman, pakaian, kendaraan, properti dan lain sebagainya. Kelima, menjual sesuatu itu hanya atas barang yang mampu untuk diserahkannya. Makanya yang dinamakan future trading itu haram, karena yang diperjualbelikan hanya sekedar catatan saja bukan barangnya sendiri. Ke enam, hendaklah barang yang diperjualbelikan itu diketahui oleh kedua belah pihak dengan melihat atau menyaksikan ketika berakad, atau dengan menjelaskan sifat-sifatnya. Ketujuh, harga dari barang yang hendak diakadkan harus jelas, dengan membatasi harga barang yang hendak diakadkan dan kita mengetahui harga barang tersebut. Umpamanya kita tahu harga suat barang adalah 500. Tapi kita menjadi kesal karena ada suatu tempat yang menjualnya dengan harga 5.000 yang jauh lebih tinggi dari harga yang kita ketahui. Ini tidak sah jual belinya, kecuali terpaksa. Atau misalkan kita ridho dengan harga yang ditawarkan, maka tidak masalah.

Hak khiyar dalam transaksi jual beli, secara etimologi khiyar adalah berasal dari bentuk mashdar yang berasal dari Ikhtiyar yang berari Memilih, terbebas dari aib, dan melaksanakan pemilihan. Sedangkan secara terminologi khiyar mempunyai beberapa pengertian namun dapat disimpulkan, "khiyar adalah hak orang yang melakukan transaksi ('aqid) untuk membatalkan transaksi atau meneruskannya karena adanya alasan syar'i yang memboehkannya atau karena kesepakatan dalam transaksi Dapat dikatakan juga bahwa khiyar adalah tuntutan untuk memilih dua hal: meneruskan transaksi atau membatalkannya.

Dalam pengklasipikasi khiyar ini, para ahli (ulama) terjadi perselisihan pendapat. Menurut Hanafiyah khiyar jumlahnya ada 17 macam. Menurut Malikiyah jumlahnya ada 2 macam yaitu: Khiyar At-ta'ammul (melihat, meneliti), yakni khiyar secara mutlak. Khiyar Naqish ( kurang ), yakni apabila terdapat 
kekurangan aib pada barang yang dijual ( khiyar al-hukmy), khiyarnya menjadi batal. Syafi'iyah jumlah khiyar ada 2 macam: At-tasyhir dan Khiyar Naqishah. Menurut Imam Hanbali ada 8 macam.

Namun penulis disini hanyalah akan menyuguhkan dan mengkaji pembagian khiyar sebagian saja, yang sering terjadi di masyarakat, yaitu antara lain:

a. Khiyar Majlis

Khiyar majlis adalah pembeli dan pembeli masih dalam tempat ketika melakukan transaksi jual beli.

Mulai berlakunya khiyar majlis disini adalah ketika dimulai saat terjadinya transaksi. Yakni setelah terjadi ijab dan qabul. Masa berlakunya khiyar ini menurut Abu Hanifah dan Asy-Syafi'ie yaitu tidak boleh melebihi 3 hari. Sedangkan malikiyah membolehkan melebihi 3 hari sesuai dengan kebutuhan. Yang shahih (benar), khiyar merupakan hak yang bergantung pada syarat, maka perkiraannya tergantung pada orang yang membuat syarat.

b. Khiyar Syarat

Khiyar syarat adalah Khiyar syarat yaitu khiyar yang dijadikan syarat sewaktu akad oleh keduanya atau oleh salah seorang, seperti kata si penjual," saya jual barang ini dengan harga sekian dengan syarat khiyar dalam tiga hari atau kurang dari tiga hari. Khiyar syarat boleh dilakukan dalam segala macam jual beli, kecuali barang yang barang-barang riba.

Batasan khiyar, mengenai batasan khiyar ini ada beberapa pendapat diantaranya : Hanafiyah, jafar dan syafi'iyah berpendapat bahwa khiyar dibolehkan dengan waktu yang ditentukan selagi tidak lebih dari tiga hari. Karena menurut mereka waktu tiga hari itu cukup untuk memenuhi kebutuhan seseorang. Dengan demikian jika melewati tiga hari, jual - beli tersebut batal. Akad tersebut akan tetap menjadi shahih jika tidak melewati batas tiga hari, akan tetapi jika melewati tiga hari maka akadnya menjadi tidak sah. Imam syafi'I berpendapat khiyar yang melebihi tiga hari membatalka jual - beli, sedangkan bila kurang dari tiga hari, hal itu adalah rukhsah ( keringanan ). Hambali berpendapat khiyar itu diperbolehkan menurut kesepakatan orang yang berakad, baik sebentar maupun lama, sebab khiyar syarat sangat berkaitan dengan orang yang memberi syarat. Malikiyah berpendapat bahwa khiyar syarat dibolehkan sesuai kebutuhan.

c. Khiyar 'Aib

Khiyar aib adalah khiyar yang sebabnya adanya 'aib (cacat).

Perkara yang menghalangi untuk mengembalikan barang yang cacat tidak boleh dikembalikan karena adanya hal - hal sebagai berikut :11 
1) Rida setelah mengetahui adanya cacat

2) Menggurkan khiyar

3) Barang rusak karena perbuatan pembeli

4) .Adanya tambahan pada barang yang bersatu dengan barang tersebut dan bukan berasal dari aslinya atau terpisah dari barangnya.

d. Khiyar Ru'yah

Khiyar ru'yah adalah hak pembeli untuk membatalkan akad atau tetap melangsungkannya ketika ia melihat obyek akad dengan syarat ia belum melihatnya ketika berlangsung akad atau sebelumnya ia pernah melihatnya dalam batas waktu yang memungkinkan telah jadi batas perubahan atasnya. ${ }^{12}$ Konsep khiyar ini disampaikan oleh ulama Hanafiyah, Malikiyah, Hanabilah dan Dhahiriyah dalam kasus jual beli benda yang ghaib (tidak ada di tempat) atau benda yang belum pernah di periksa. Namun imam Syafi'ie menyangkal keberadaan Khiyar ru'yat ini, karena menurutnya jual beli terhadap barang yang ghaib (tidak ada ditempat) sejak semula sudah tidak sah. Syarat Khiyar Ru'yah bagi yang membolehkannya antara lain:13

e. Khiyar ta'yin

Yang dimaksud dengan khiyar ta'yin adalah hak yang dimiliki oleh orang yang menyelenggarakan akad (terutama pembeli) untuk menjatuhkan atau memastikan pilihan atas sejumlah benda sejenis dan setara sifat atau harganya. Biasanya barang yang dijual memiliki tiga kualitas yaitu biasa, menengah dan istimewa. Pembeli diberikan hak pilih (ta'yin) untuk mendapatkan barang yang terbaik menurut penilaiannya sendiri tanpa menadapatkan tekanan dari manapun juga.

\section{Ukuran takaran dan timbangan}

Seorang penjual atau pembeli harus membuat takaran atau timbangan yang benar, sehingga pembelia atau penjual tidak merasa ada yang menipu. Larangan mengurangi takaran atau timbungan berdasarkan Firman Allah SWT.dalam Surah al-A 'raf ayat 85, al-Muthaffin : 1-3.

\section{Mengambil hak orang lain}

Dilarang mengambil hak orang lain atau yang bukan hak kita. Contoh. Menggeser atau memindahkan batas tanah dari yang sebenarnya ketempat lain, tanpa seizin atau tanpa sepengetahuan yang punya tanah yang lainnya.

\section{KESIMPULAN}

${ }^{12}$ Ghufron A. Mas'adi. Fiqh Muamalah Kontekstual....., 113

${ }^{13} \mathrm{Ibid}$. 
Kesimpulan dalam penelitian ini tenteng etika (akhlak) yang harus dimiliki seorang pedagang, yaitu:

1. Memiliki kepribadian spiritual (taqwa)

2. Berkepribadian baik dan simpatik (shiddiq)

3. Berlaku adil dalam berbisnis (al-'adl)

4. Melayani nasabah dengan rendah hati (khitmah)

5. Selalu menepati janji dan tidak curang (tahfif)

6. Jujur dan terpercaya (amanah)

7. Tidak suka berburuk sangka

8. Tidak suka menjelek-jelekkan

9. Tidak melakukan suap (risywah).

Pedagang boleh melakukan sistem hutang piutang dengan konsumen untuk memasarkan barangnya. Hutang piutang yang dilakukan tidak boleh mengandung unsur riba. Konsumen tidak boleh melalaikan pembayaran hutangnya kepada pedagang, supaya tidak terjadi perselisihan. Dalam menentukan harga dagangannya, pedagang harus memberikan harga yang sesuai harga pasar kepada setiap konsumen. Pedagang harus memberikan hak khiyar bagi konsumen, sesuai aturan khiyar dalam hukum islam.

Apabila telah demikian etika para pengusaha dalam melayani pelanggan, maka para konsumen akan berbelanja dan meningkat daya beli di toko-toko pedagang muslim. 
121 Tazkir Vol. 01 No. 2 Juli-Desember 2015

\section{DAFTAR PUSTAKA}

Azhar Akmal Tarigan dkk, Dasar-dasar Ekonomi Islam, (Bandung: Cita Pustaka Mulia, 2006).

Buchari Alma, Dasar-dasar Etika Bisnis Islam, (Bandung: Alfabeta,2003).

Ghufron A. Mas'adi. Fiqh Muamalah Kontekstual, PT Raja Grafindo Persada, 2002.

Lexy Moleong, Metodologi Penliltian Kualitatif, (Bandung: Remaja Rosda karya: 1989).

Michael P. Todaro, Pembangunan Ekonomi Di Dunia Ketiga, (Jakarta, Edisi Ke Enam Penerbit Erlangga, 1999).

Rachmat Syafe'I, Figh Muamalat, (Bandung : Pustaka Setia, 2006)

Riduwan, Belajar Muda Penelitian Untuk Guru-Karyawan dan Peneliti Pemula,(Bandung, Alfabeta,2005).

Sayyid Sabiq, Fiqh Sunnah, (Mesir: Dar alFikr, 1983), jilid, III

\section{WAWANCARA}

Wawan.cara dengan seorang pedagang di Pasar Sagumpal Bonang pada bulan Nopember 2012.

Wawancara dengan para Pedagang Grosir Pusat Pasar Kota Padangsidimpuan bulan Nopember 2012

Wawancara dengan pedagang kain di Pasar Sagumpal Bonang dan Pelaza Anugrah pada bulan Nopember 2012

Wawancara yang dilakukan terhadap para pembeli di pusat Pasar Sagumpal Bonang Kota Padangsidimpuan bulan Nopember 2012 